\title{
Occurrence of adult female Kitefin shark Dalatias licha (Bonnaterre, 1788) in Iskenderun Bay (Eastern Mediterranean, Turkey)
}

\author{
Deniz ERGÜDEN¹', Mustafa ÇEKIÇ², Sibel ALAGÖZ ERGÜDEN³, Ayhan ALTUN¹, Necdet UYĞUR \\ ${ }^{1}$ Marine Sciences and Technology Faculty, Iskenderun Technical University, Iskenderun-Hatay, Turkey \\ ${ }^{2}$ Hatay School of Health, Mustafa Kemal University, Antakya, Hatay, Turkey \\ ${ }^{3}$ Imamoglu Vocational School, Cukurova University, Imamoglu, Adana, Turkey \\ ${ }^{4}$ Maritime Vocational School, Iskenderun Technical University, Iskenderun, Hatay, Turkey
}

\begin{abstract}
Received: 27.11 .2017
Accepted: 14.12.2017

Available online: 25.12 .2017

Published: 29.12.2017

Abstract: A single female specimen of the Kitefin shark Dalatias licha (Dalatiidae), $118 \mathrm{~cm}$ in total length (TL), was caught by a commercial trammel net at a depth of $40 \mathrm{~m}$ on 11th June 2016 off the Çevlik coast (Eastern Mediterranean), Turkey. The present paper was the first confirmation of an adult female specimen of $D$. licha from the Mediterranean coast of Turkey. Measurements of the specimen were given and the geographical distribution of the species in the Mediterranean was documented.

Keywords: Dalatiidae, Dalatias licha, Iskenderun bay, Eastern Mediterranean

\section{İskenderun Körfezi'nde (Doğu Akdeniz Bölgesi) Ergin Dişi Uçurtma Yüzgeçli Köpekbalığı, Dalatias licha'nın (Bonnaterre, 1788) Varlığı}

Özet: Türkiye'nin Çevlik (Doğu Akdeniz) sahillerinden 11 Haziran 2016 tarihinde $118 \mathrm{~cm}$ toplam boyunda uçurtma yüzgeçli köpek balığı, Dalatias licha'nın tek bir dişi bireyi ticari troll ağı ile $40 \mathrm{~m}$ derinlikten avlanmıştır. Sunulan bu makale yetişkin dişi bir birey D. licha'nın Türkiye'nin Akdeniz sahillerinden ilk teyididir. Örneğin ölçümleri yapılarak bu türün Akdeniz'deki coğrafik dağılımı belgelenmiştir.
\end{abstract}

Anahtar kelimeler: Dalatiidae, Dalatias licha, Iskenderun körfezi, Doğu Akdeniz

The Kitefin shark is a deep-water species, benthic to mesopelagic species, and mainly distributed in the western Atlantic, western Indian Ocean, and Pacific Ocean (Compagno 1984, Last and Stevens 1994). However, the range of this species in the Mediterranean appears to be confined to the western and central basins of the Mediterranean (Baino et al 2001). The occurrence of the species in eastern Mediterranean is highly rare and the first report in the area was documented by Akşıray (1987). Then, Papaconstantinou (1988) reported the presence of the kitefin shark in the Aegean Greek waters. Seven years later, Meriç (1995) also reported the species off the Turkish coasts of eastern Mediterranean. Kabasakal and Kabasakal (2002) indicated the presence of the species in northeastern Aegean Sea with the record of five young kitefin shark specimens during breeding season off the northern coast of Gokçeada in 1999. Further reports of the species have been documented several times off the western Mediterranean (Bottaro et al 2003, Bottaro et al 2005, Capape et al 2008) and Levantine coasts (Golani 2004, Saad et al 2004) up to now.

Special importance of this paper is that it represents the first record of an adult female specimen of D. licha in Iskenderun Bay (Eastern Mediterranean, Turkey).

A single female specimen of $D$. licha (Figure 1 and Figure 2) was caught off the Çevlik coast (Iskenderun Bay), ( $\left.36^{\circ} 07^{\prime} \mathrm{N}, 35^{\circ} 54^{\prime} \mathrm{E}\right)$ on 11th June 2016 during commercial fishing with a trawling at a depth of $40 \mathrm{~m}$ (Figure 3). All morphometric measurements were made to the nearest $0.01 \mathrm{~mm}$ using digital calipers. All measurements and counts, and the morphological description and color are consistent with the descriptions of Compagno (1984) and Kabasakal and Kabasakal (2002).

The kitefin shark, D. licha, is moderately sized, short, and blunt-snouted shark with two almost equal-sized dorsal fins; no spines are associated with dorsal fins and the species does not have an anal fin. Small slendercusped upper teeth and very large lower teeth are distinctively triangular and serrated. First dorsal fin originates behind the rear tips of pectoral fin and its base is closer to the pectoral base than the pelvic fins. Caudal fin with the ventral lobe is not expanded and the tail has a well-developed upper half with a large terminal lobe (Compagno 1984). Color: Body is brown to greyish. The dorsal surface has poorly defined black spots, margins of the fins is translucent, and the tip of the tail is black (Cox and Francis 1997). Distinguishing morphometric characters are given in Table 1 and previous reports of the D. licha in the Mediterranean Sea are summarized in Table 2.

Although more common length of this species is 120 $\mathrm{cm}$ in total length, the maximum size of kitefin shark has been reported to be $180 \mathrm{~cm}$ by Bauchot (1987). The size at birth is approximately $30 \mathrm{~cm}$ in total length (Bigelow and Shroeder 1948, Bauchot 1987, Whitehead et al 1984-1986). The length of maturity for males and for females ranges between 77-121 cm and 117-159 cm, respectively (Compagno 1984, Bauchot 1987). The kitefin shark feeds 
mainly on deep-water bony fish. However, its diet also includes skates, other sharks, cephalopods, and crustaceans (Compagno et al 1989).

Table 1: Morphometric measurements $(\mathrm{mm})$ and percentage values (\%) of the kitefin shark D. licha off the Cevlik coast, Turkey

\begin{tabular}{|c|c|c|}
\hline Measurement & $\mathrm{mm}$ & $\%$ \\
\hline Sex & 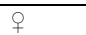 & \\
\hline Total length & 1180 & - \\
\hline Head length & 250.40 & 21.22 \\
\hline Head width & 116.62 & 9.88 \\
\hline Eye length & 41.16 & 3.48 \\
\hline Eye height & 20.58 & 1.74 \\
\hline Interorbital space & 72.03 & 6.10 \\
\hline Eye spiracle space & 27.44 & 2.32 \\
\hline Spiracle length & 10.29 & 0.87 \\
\hline Mouth length & 85.75 & 7.26 \\
\hline Mouth width & 62.76 & 5.32 \\
\hline Nostril width & 20.58 & 1.74 \\
\hline Internarial space & 34.30 & 2.90 \\
\hline Anterior nasal flap length & 6.86 & 0.58 \\
\hline Pre-branchial length & 202.38 & 17.15 \\
\hline Pre-spiracular length & 113.19 & 9.59 \\
\hline Pre-orbital length & 48.02 & 4.06 \\
\hline Pre-narial length & 24.01 & 2.03 \\
\hline Pre-oral length & 72.03 & 6.10 \\
\hline Pre-first dorsal length & 418.48 & 35.46 \\
\hline Pre-second dorsal length & 706.60 & 59.88 \\
\hline Pre-pectoral length & 257.26 & 21.80 \\
\hline Pre-pelvic length & 638.02 & 54.06 \\
\hline Pre-caudal length & 885.01 & 75.00 \\
\hline Snout-vent length & 706.62 & 59.88 \\
\hline First dorsal length & 109.76 & 9.30 \\
\hline Second dorsal length & 120.05 & 10.17 \\
\hline Pelvic length & 130.34 & 11.04 \\
\hline Pectoral length & 168.08 & 14.24 \\
\hline Interdorsal space & 250.40 & 21.22 \\
\hline Dorsal-caudal space & 123.48 & 10.46 \\
\hline Pectoral-pelvic space & 343.23 & 29.08 \\
\hline Pelvic caudal space & 140.63 & 11.91 \\
\hline Vent-caudal length & 473.37 & 40.11 \\
\hline Intergill length & 54.88 & 4.65 \\
\hline First gill slit height & 17.15 & 1.45 \\
\hline Second gill slit height & 17.56 & 1.48 \\
\hline Third gill slit height & 18.25 & 1.54 \\
\hline Fourth gill slit height & 18.77 & 1.59 \\
\hline Fifth gill slit height & 20.58 & 1.74 \\
\hline Trunk width & 126.91 & 10.75 \\
\hline Abdomen width & 106.33 & 9.01 \\
\hline Tail width & 54.88 & 4.65 \\
\hline Caudal peduncle width & 30.87 & 2.61 \\
\hline
\end{tabular}

Recently, deep-water fishing activity is commonly performed throughout the northeastern Mediterranean area and the kitefin sharks in the region are caught mainly as bycatch of bottom trawling and deep longline and gillnet fisheries. Slow growth rate, late sexual maturity, and long gestation period in its life span make this species vulnerable (Hoenig and Gruber 1990, Stevens et al 2000). Nevertheless, little information is available on the biology of this species inhabiting Mediterranean waters and it is rarely found in the northeastern Mediterranean.

Conservation status of the kitefin shark, D. licha in the Mediterranean Sea is recognized as data deficient "DD" by Abdul Malak et al (2011). However, the species has been globally considered as near threatened "NT" in the Global Red List of the Blasdale et al (2009). Increased deep-water fishing effort is likely to affect kitefin shark populations in the near future. Rapid decline of the species could be related to growing fisheries industry relying on deep-water longline and gill net for several decades. Therefore, there is a need for urgent investigation on the biology of this species in order to determine the conservation strategies for $D$. licha in the Mediterranean Sea.

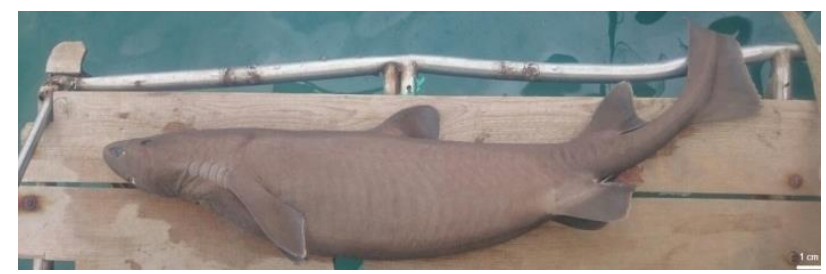

Figure 1: Dalatias licha (TL, $118 \mathrm{~cm})$ collected off the Cevlik coast (eastern Mediterranean Sea, Turkey)

Although D. licha was reported from the Mediterranean Sea, the northeastern Aegean Sea, and Marmara Sea, this paper also confirms the presence of the species in Iskenderun Bay, Turkey (eastern Mediterranean) with the first reports of an adult female specimen of $D$. licha.

Table 2: Records of $D$. licha in the western and eastern Mediterranean Sea covering 1987-2017 (Sx: Sex, D: Depth, TL: Total Length).

\begin{tabular}{|c|c|c|c|c|c|c|}
\hline References & Year & Location & $\mathrm{N}$ & Sx & $\begin{array}{l}\mathrm{D} \\
(\mathrm{m})\end{array}$ & $\begin{array}{l}\mathrm{TL} \\
(\mathrm{cm})\end{array}$ \\
\hline Akşıray (1987) & 1985 & $\begin{array}{l}\text { Turkey } \\
\text { Seas }\end{array}$ & 1 & - & - & 150.0 \\
\hline Meriç (1995) & July 1991 & $\begin{array}{l}\text { Sea of } \\
\text { Marmar } \\
\text { a, } \\
\text { Turkey }\end{array}$ & 1 & $\hat{o}$ & 270 & 34.5 \\
\hline $\begin{array}{l}\text { Papaconstantinou } \\
\text { (1998) }\end{array}$ & 1998 & $\begin{array}{l}\text { Greek } \\
\text { Seas }\end{array}$ & 1 & - & - & - \\
\hline $\begin{array}{l}\text { Kabasakal and } \\
\text { Kabasakal (2002) }\end{array}$ & $\begin{array}{l}\text { October } \\
1999\end{array}$ & $\begin{array}{l}\text { Gökçead } \\
\text { a coast, } \\
\text { (northea } \\
\text { stern } \\
\text { Aegean } \\
\text { Sea, } \\
\text { Turkey }\end{array}$ & 5 & $\hat{o}$ & 380 & $\begin{array}{l}33.8- \\
47.0\end{array}$ \\
\hline Bottaro et al. (2003) & $\begin{array}{l}\text { January } \\
2003\end{array}$ & $\begin{array}{l}\text { off } \\
\text { Genoa } \\
\text { (Liguria } \\
\text { n Sea) }\end{array}$ & 57 & $\begin{array}{l}\text { + } \\
\hat{0}\end{array}$ & $450-800$ & $\begin{array}{l}35.5- \\
116.4 \\
\\
36.9- \\
955\end{array}$ \\
\hline Bottaro et al. (2005) & $\begin{array}{l}\text { January } \\
2003\end{array}$ & $\begin{array}{l}\text { off } \\
\text { Genoa } \\
\text { (Liguria } \\
\text { n Sea), } \\
\text { Italy }\end{array}$ & 1 & o & $450-800$ & 90.0 \\
\hline \multirow{2}{*}{$\begin{array}{l}\text { Capape et al. } \\
(2008)\end{array}$} & $\begin{array}{l}1996- \\
2007\end{array}$ & $\begin{array}{l}\text { Algerian } \\
\text { coast }\end{array}$ & 39 & d/9 & $200-600$ & $\begin{array}{l}32.0- \\
117.0\end{array}$ \\
\hline & $\begin{array}{l}1970- \\
2007\end{array}$ & $\begin{array}{l}\text { Tunusia } \\
\mathrm{n} \text { coast }\end{array}$ & 8 & o/ $/$ ㅇ & $200-600$ & $\begin{array}{l}32.0- \\
39.0\end{array}$ \\
\hline This study (2017) & $\begin{array}{l}\text { June } \\
2016\end{array}$ & $\begin{array}{l}\text { Iskender } \\
\text { un Bay, } \\
\text { Turkey }\end{array}$ & 1 & 우 & 40 & 118.0 \\
\hline
\end{tabular}

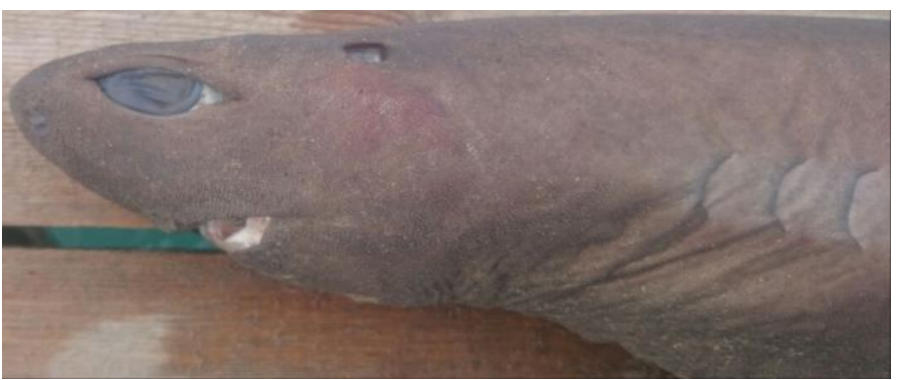

Figure 2: Head view of Dalatias licha 


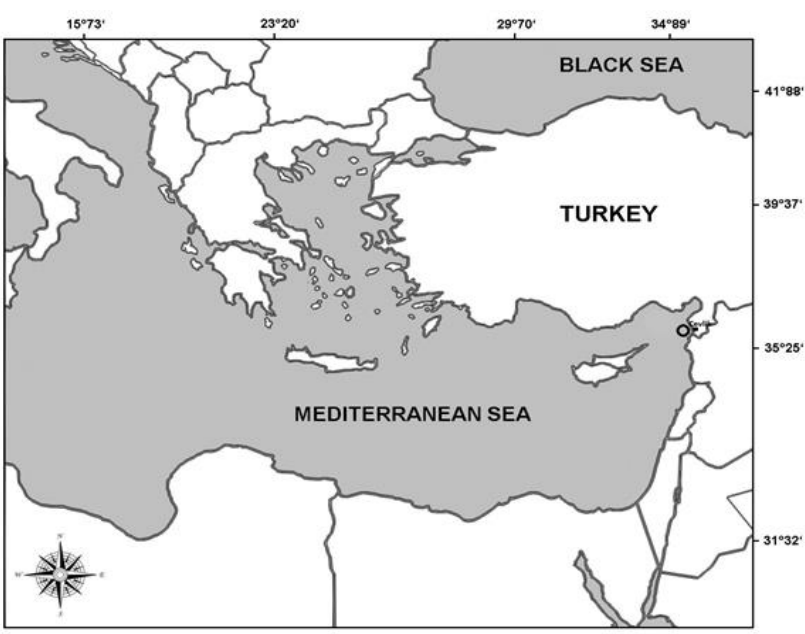

Figure 3: Map showing capture site (o) of Dalatias licha in eastern Mediterranean (Iskenderun Bay, Turkey)

\section{References}

Abdul Malak, D., Livingstone, S. R., Pollard, D., Polidoro, B. A., Cuttelod, A., Bariche, M., Bilecenoglu, M., Carpenter, K. E., Collette, B. B., Francour, P., Goren, M., Kara, M. H., Massutí, E., Papaconstantinou, C., Tunesi, L. 2011: Overview of the Conservation Status of the Marine Fishes of the Mediterranean Sea. Switzerland and Malaga, Spain: IUCN, Gland.

Akşıray, F. 1987: Türkiye Deniz Balıkları ve Tayin Anahtarı. 2nd Ed. Istanbul: Publications of Istanbul University, Turkey.

Baino, R., Serena, F., Ragonese, S., Rey, J., Rinelli, P. 2001: Catch composition and abundance of elasmobranchs based on the MEDITS Program. Rapports de la Commission Internationale pour L'Exploration Scientifique de la Mer Mediterranee, 36: 234.

Bauchot, M. L. 1987: Poissons osseux. pp. 891-1421. In: Fischer, W., Bauchot, M.L., Schneider, M. (eds.), Fiches FAO d'identification pour les besoins de la pêche. (rev. 1). Méditerranée et mer Noire. Zone de pêche 37. Vol. II. Rome: Commission des Communautés Européennes and FAO.

Bigelow, H. B., Schroeder, W. C. 1948: Sharks. pp. 59-576. In: Tee-Van, J., Breder, C.M.., Hildebrand, S.F., Parr, A.E., Schroeder, W.C. (eds.), Fishes of the Western North Atlantic. Mem. Sears. Found. Mar. Res. Yale University, New Haven.

Blasdale, T., Serena, F., Mancusi, C., Guallart, J., Ungaro, N. 2009: Dalatias licha. The IUCN Red List of Threatened Species. http:/ / www.iucnredlist.org, accessed date 06.09.2017.

Bottaro, M., Clo S., Dalu M., Modena, M., Vacchi M. 2003: Preliminary notes about the biology of the kitefin shark Dalatias licha (Bonnaterre, 1788) from the Gulf of Genoa. $7^{\text {th }}$ Annual European Association Meeting, San Marino, Italy.

Bottaro, M., Ferrando., S., Gallus, L., Girosi, L., Vacchi, M. 2005: First record of albinism in the deep water shark Dalatias licha. JMBA 2 Biodiversity Record, 1: 1-4.

Capapé, C., Hemida, F., Quignard, J. P., Ben Amor, M. M., Reynaud, C. 2008: Biological observations on a rare deep-sea shark, Dalatias licha (Chondrichthyes: Dalatiidae), off the Maghreb coast (south-western Mediterranean). Pan-American Journal of Aquatic Sciences, 3 (3): 355360 .

Compagno, L. J. V. 1984: FAO Species Catalogue. Vol. 4. Sharks of the world. An annotated and illustrated catalogue of shark species known to date. Part 1 - Hexanchiformes to Lamniformes. FAO Fish. Synop. 125(4/1), FAO, Rome.

Compagno, L. J. V., Ebert, D. A., Smale, M. J. 1989: Guide to the sharks and rays of southern Africa. New Holland (Publ.) Ltd., England.

Cox, G., Francis, M. 1997: Sharks and rays of New Zealand. University of Canterbury. Canterbury Univ. Press, England.

Golani, D. 2004: Check-list of the Mediterranean Fishes of Israel. Zootaxa, 947: 1-200.
Hoenig, J. M., Gruber, S. H. 1990: Life-history patterns in the elasmobranchs: implications for fisheries management. NOAA Technical Report NMFS, 90: 1-16.

Kabasakal, H., Kabasakal, E. 2002: Morphometrics of young kitefin sharks, Dalatias licha (Bonnaterre, 1788), from Northeastern Aegean Sea, with notes on its Biology. Annales, Series Historia Naturalist, 12(2): 161-166.

Last, P. R., Stevens, J. D. 1994: Sharks and Rays of Australia. CSIRO Division of Fisheries. Melbourne, Australia.

Meriç, N. 1995: A study on existence of some fishes on the continental slope of Sea of Marmara. Turkish Journal of Zoology, 19(2): 191-198.

Papaconstantinou, C. 1998: Check list of marine fishes of Greece. National Center for Marine Research \& Hellenic Zoological Society (Ed.), Athens, Greece.

Saad, A., Séret, B., Ali, M. 2004: Liste commentée des Chondrichthyens de Syrie. Rapport de la Commission internationale pour l' Exploration de la Mer Méditerranée 37: 430.

Stevens, J. D., Bonfill, R., Dulvy, N. K., Walker, P. A. 2000: The effects of fishing on sharks, rays, and chimaeras (chondrichthyans), and the implications for marine ecosystems. ICES Journal of Marine Science, 57: 476-494.

Whitehead, P. J. P., Bauchot, M. L., Hureau, J. C., Nielsen, J., Tortonese, E. (eds.) 1984-1986: Fishes of the North-eastern Atlantic and the Mediterranean. UNESCO, Paris. 